\title{
Administration Performance Evaluation System of Water Environment Protection
}

\author{
Zhiyi Lei ${ }^{1}, a^{*}$, Liling Chen ${ }^{1, b}$ \\ ${ }^{1}$ College of Harbour, Coastal and Offshore Engineering, Hohai University, Nanjing, China \\ alei_zhiyi@hhu.edu.cn, b1297762489@qq.com
}

\begin{abstract}
Keywords: Administration performance, Index system, Measures
Abstract. Based on the study on the water environment management system and operation mechanism of Qinhuai river, for the water quality improvement and sustainable function to enhance the public management demand, the long-term plan to improve the water quality of the Qinhuai River is put forward, in which the evaluation system of water environmental protection performance is established to improve the management efficiency.
\end{abstract}

\section{Introduction}

In recent years, the sewage into the Qinhuai River mainly comes from industrial waste water and residents, hotels, restaurants, hospitals and other emissions of domestic sewage. According to statistics, the Qinhuai River basin, accept the sewage of about 1 million 50 thousand tons. Pollution management can't be ignored [1].

"Green government" has become a new concept of government administration. The environmental performance into the government performance evaluation system, help to guide and promote the local government to actively change the development concept in the system, and change the only indicator of government performance to ensure sustainable economic development [2].

\section{Government Environmental Performance Indicators}

The evaluation system of government environmental performance is a systematic project, which requires great efforts to study and practice. Here we conceived an index framework, some indexes remain to be discussed and improved. Referring to the research achievements of scholars at home and abroad as well as the definition of government functions, the evaluation of environmental performance of government is divided into three layers, the function index, efficiency index, potential index, which consists of 3 level indexes, 8 level two indexes and 23 level three indexes. Of course, each department can increase or decrease the indexes considering its specific circumstances. The index system is shown in Table 1.

The function index is the index of measuring the function performance, which is the performance level of the government in its function scope. It examines the basic functions of government environmental management. Environmental supervision is a law enforcement activities, first is the degree of perfection of environmental laws and regulations, followed by normative and efficiency of environmental law enforcement, embodied in satisfaction for the law enforcement and service object (enterprise).

Benefit index is indirect and fundamental, to measure the effectiveness of government environmental protection and its contribution to the whole social economic development. This index directly examines all environmental effects of the government. The index of environmental infrastructure construction is the symbol of people's living environment level. The environmental improvement benefit is the reflection of environmental protection work. Citizen satisfaction is the ultimate standard for testing public service quality.

The performance of government environmental governance is reflected in the changes of the external environment, but also reflected in its internal management and ability. Potential indexes reflect the level of management within the government. It is the basis of fulfilling the environmental 
protection function and the guarantee of government environmental performance continuous improvement. Potential indexes include administrative organizations and environmental research.

Table 1. Government Environmental Performance Indicators

\begin{tabular}{|c|c|c|c|c|c|c|}
\hline \multirow{2}{*}{ Criteria } & \multirow{2}{*}{ Factor } & \multirow{2}{*}{ Indicators } & \multicolumn{4}{|c|}{ Grade } \\
\hline & & & $\mathrm{I}$ & II & III & IV \\
\hline \multirow{12}{*}{$\begin{array}{c}\text { Function } \\
\text { index }\end{array}$} & \multirow{2}{*}{ laws } & $\begin{array}{l}\text { Environmental Law } \\
\text { Enforcement }\end{array}$ & Very large & General & Small & no execute \\
\hline & & $\begin{array}{c}\text { Number of Environmental } \\
\text { Regulations }\end{array}$ & $>5$ & $3 \sim 5$ & $1 \sim 3$ & $<1$ \\
\hline & \multirow{4}{*}{ management } & $\begin{array}{c}\text { Environmental Impact } \\
\text { Assessment Implementation } \\
\text { Rate } \\
\end{array}$ & $100 \%$ & $90 \% \sim 99 \%$ & $80 \sim 89 \%$ & $<80 \%$ \\
\hline & & $\begin{array}{l}\text { "Three Simultaneous" } \\
\text { Implementation Rate }\end{array}$ & $100 \%$ & $90 \% \sim 99 \%$ & $80 \% \sim 89 \%$ & $<80 \%$ \\
\hline & & $\begin{array}{c}\text { Environmental Administrative } \\
\text { PenaltyRate }\end{array}$ & $100 \%$ & $90 \% \sim 99 \%$ & $80 \% \sim 89 \%$ & $<80 \%$ \\
\hline & & $\begin{array}{c}\text { Cleaner Production Audit Rate } \\
\text { of Key Enterprises }\end{array}$ & $100 \%$ & $80 \% \sim 99 \%$ & $60 \% \sim 79 \%$ & $<60 \%$ \\
\hline & \multirow{2}{*}{ propaganda } & $\begin{array}{c}\text { Regularly Publish } \\
\text { Environmental Quality Report }\end{array}$ & Regular & $\begin{array}{l}\text { Publishi but not } \\
\text { Regular }\end{array}$ & not to publish & not to publish \\
\hline & & $\begin{array}{c}\text { Environmental Publicity } \\
\text { Activities }\end{array}$ & $>5$ & $3 \sim 5$ & $1 \sim 3$ & $<1$ \\
\hline & \multirow{4}{*}{ Efficiency } & $\begin{array}{l}\text { National Environmental } \\
\text { Protection Model City or } \\
\text { Ecological City } \\
\end{array}$ & Both & One & Being declared & Being created \\
\hline & & $\begin{array}{l}\text { Environmental Complaint } \\
\text { Completion Rate }\end{array}$ & $100 \%$ & $90 \% \sim 99 \%$ & $80 \% \sim 89 \%$ & $<80 \%$ \\
\hline & & $\begin{array}{l}\text { Total Control Completion } \\
\text { Rate }\end{array}$ & $100 \%$ & $90 \% \sim 99 \%$ & $80 \% \sim 89 \%$ & $<80 \%$ \\
\hline & & $\begin{array}{c}\text { Annual Implementation Rate } \\
\text { of Environmental Protection } \\
\text { Plan }\end{array}$ & $100 \%$ & $90 \% \sim 99 \%$ & $80 \% \sim 89 \%$ & $<80 \%$ \\
\hline \multirow{6}{*}{$\begin{array}{c}\text { Benefit } \\
\text { index }\end{array}$} & \multirow{4}{*}{$\begin{array}{c}\text { Water } \\
\text { Environment } \\
\text { Benefit }\end{array}$} & $\begin{array}{c}\text { Centralized Treatment Rate of } \\
\text { Municipal Sewage }\end{array}$ & $>80 \%$ & $70 \% \sim 80 \%$ & $60 \% \sim 69 \%$ & $<60 \%$ \\
\hline & & $\begin{array}{c}\text { Surface Water Quality } \\
\text { Reaches I-III Class Proportion }\end{array}$ & $>60 \%$ & $40 \% \sim 59 \%$ & $20 \% \sim 39 \%$ & $<20 \%$ \\
\hline & & $\begin{array}{c}\text { Industrial Wastewater } \\
\text { Discharge Compliance Rate }\end{array}$ & $100 \%$ & $90 \% \sim 99 \%$ & $80 \% \sim 89 \%$ & $<80 \%$ \\
\hline & & Green Coverage Rate & $>35 \%$ & $25 \% \sim 35 \%$ & $15 \% \sim 25 \%$ & $<15 \%$ \\
\hline & \multirow[b]{2}{*}{ Social benefit } & $\begin{array}{c}\text { Frequency of Environmental } \\
\text { Accidents }\end{array}$ & 0 & 5 & $>10$ & $>15$ \\
\hline & & $\begin{array}{c}\text { Public Satisfaction With } \\
\text { Water Environmental } \\
\text { Protection } \\
\end{array}$ & $>85 \%$ & $75 \% \sim 85 \%$ & $65 \% \sim 75 \%$ & $<65 \%$ \\
\hline \multirow{5}{*}{$\begin{array}{c}\text { Potential } \\
\text { index }\end{array}$} & \multirow{3}{*}{$\begin{array}{l}\text { Administrative } \\
\text { Organization }\end{array}$} & $\begin{array}{l}\text { Water Environmental } \\
\text { Protection Investment }\end{array}$ & $>1.7 \%$ & $1.2 \% \sim 1.7 \%$ & $0.7 \% \sim 1.2 \%$ & $<0.7 \%$ \\
\hline & & $\begin{array}{c}\text { Number of Water } \\
\text { Environmental Protection } \\
\text { Agencies }\end{array}$ & $\begin{array}{l}\text { increase year } \\
\text { after year }\end{array}$ & Unchanged & Unchanged & Decrease \\
\hline & & \begin{tabular}{|c|} 
Training and Communication \\
of Water Environmental \\
Managers
\end{tabular} & $>40$ & $30 \sim 40$ & $10 \sim 30$ & $<10$ \\
\hline & & $\begin{array}{c}\text { Number of Scientific Research } \\
\text { on Water Environment }\end{array}$ & $>10$ & $5 \sim 10$ & $3 \sim 5$ & $<3$ \\
\hline & Research & $\begin{array}{c}\text { Number of Environmental } \\
\text { Science Awards }\end{array}$ & $>5$ & $3 \sim 5$ & $1 \sim 3$ & $<1$ \\
\hline
\end{tabular}

Needs to be emphasized is the diversity of government environmental performance appraisal and the influence of different departments on the environment. Different types of projects may not use the same evaluation standard, therefore, the indexes system is not suitable for all departments and all 
project environmental performance. Auditors must according to the specific characteristics of the audit project, targeted to set and select the appropriate evaluation index system.

\section{Evaluation Criteria}

International Standard. IS014031 standards take into account the organization's geographical, environmental and technical conditions, it does not set specific environmental performance indicators, providing a "environmental performance indicators". So Environmental Performance Indicators ( EPIs) can be divided into the Environmental Condition Indicators ( ECls) and the EPIs internal organization which can be divided into Management Performance Indicators( MPIs) and Operational Performance Indicators (OPIs). At the same time, environmental performance audit standards include environmental protection law, environmental protection management system, environmental protection technology standards, international contracts, etc.

Domestic Standard. The classification standards include water environmental protection standards, atmospheric environmental protection standards, environmental noise and vibration standard, soil environmental protection standards, solid waste and chemicals environmental pollution control standards, nuclear radiation and electromagnetic radiation environmental protection standards, environmental protection standards and other standards for environmental protection.

\section{Determination of Evaluation Criteria}

According to the evaluation principles and standards according to our country, the government environmental performance indicators are divided into four levels, namely the first stage (85 100), second (70 84), third (60 69), fourth (60 points). Among them, some indicators are difficult to be classified, such as the number of environmental advocacy activities, environmental research, etc., can be directly scoring. In order to avoid the inconsistency between different levels of government evaluation standards, according to the environmental performance level of our different levels of government, to city and district two sets of grading standards, to objectively reflect the government environmental performance level. The level of evaluation standard value is shown in Table 1.

\section{Safeguard Measures}

Improve the Understanding on Environmental Performance Audit. Environmental performance audit can effectively expose the problems of unreasonable exploitation and utilization of environmental funds, projects and resources, urge relevant departments to enhance environmental awareness and strictly implement environmental protection policies. It can also prompt the government to establish a good image. Attaching importance to environmental protection can improve the awareness of local governments to protect the environment in economic development, and make environmental protection more effectively participate in comprehensive decision-making to ensure the sustainable development of national economy [5].

Research and Application of Government Environmental Performance Audit Theory. The current theoretical research of environmental performance audit in China is still in an embryonic stage, for many basic problems, such as subject, scope, standards and methods are not defined. Therefore, strengthening the theoretical research on environmental performance has great significance to the practice of environmental performance audit.

Perfect Relevant System. China has promulgated 6 environmental protection laws, 13 environmental related resources protection laws and 395 environmental standards, and basically formed the environmental laws and regulations supervision system. However, we are still lack of specific implementation guidance, and lack of specific implementation of environmental audit methods and evaluation criteria. Due to the lack of relevant audit basis or evaluation criteria, auditors in the evaluation of government environmental performance is difficult, the audit risk is larger. As to the government environmental protection funds limit lack of specific provisions, the impact of environmental assets, liabilities, cost accounting and cost; some environmental effect is hard to 
measure, according to the current projections generated data, it is difficult as the basis of audit; some environmental issues for non monetary measurement, the results or loss in the accounting information disclosure of the existence of defects [3].

Improve the Environmental Protection Fund System. China's fiscal expenditure system does not have a unified and independent environmental protection funds expenditure subjects, environmental protection lack of stable funding sources [4]. The fiscal expenditure for protecting environment, although in recent years, is growing, but is mainly by sector, according to the project allocation, lack of overall planning, resulting in unreasonable allocation of funds. Funding is badly lacking in some areas of national security and long-term interests. For example, environmental law enforcement, inter basin water environment governance, National Nature Reserve Management, historical pollution treatment, international environmental convention, nuclear waste disposal facilities, a serious lack of financial support environment. And in the use of the process, the allocation of funds is chaos with low efficiency.

Train High-Quality Professional Auditors. Environmental performance audit involves environmental economics, environmental law, environmental management, sociology, statistics, engineering and other aspects of knowledge, very strong cross. At present, most of the audit staff in our country are graduates of accounting, auditing or economics, nor have they been involved in environmental performance audit. The environmental performance audit is professional and technical, different from the general financial revenue and expenditure audit and economic benefit audit, so the lack of professional environmental performance auditors is the urgent problem to be solved.

\section{Acknowledgment}

This research is financially supported by the National Natural Science Foundation of China, "Study on Wetland Area Holdings With No Ecology Function Loss" (Grant No. 51409088 ).

\section{References}

[1] Zhiyi lei, Li Yuan, Distrubution and Source Apportionment of Water Environmental Risk Factors of City River. Advanced Materials Research, 2014. v518-523.

[2] Liu E. J, Bai J. L, Think about the “Administration and Production Separation”. Water Resources Development \& Management. 2010, 2.

[3] Min song, Hongmei Wan ,Changxin Xu, et al. 2011 .An Analysis on the Government-enterprise Game in the Case of Urban Pollution Treatment. The 2011 International Conference on Green Energy And Environmental Sustainable Development November 4-6, Jilin, China.PartB Volume 23.

[4] Zhe Kai, Hengquan Zhang, et al. 2012. Study on the Implementation of "Administration and Production Separation" In Qinhuai River's Water Environmental Quality Improvement. the Second International Academic Conference on Energy, Environment and Development.

[5] Changfeng Shi, Changxin Xu, Qingmin Yin, Haozhang. Intergenerational Allocation of Resources of Coastline-from the Perspective of intergenerational Equity. International Conference of Management and Service Science (MASS2012), Aug.10-12, 2012, Shanghai, China. 